Eur J Clin Chem Clin Biochem

1995; 33:733-736

(c) 1995 Walter de Gruyter \& Co. Berlin - New York

\title{
Nested Polymerase Chain Reaction for Detection of Hepatitis C Virus RNA in Blood Derivatives
}

\author{
By Koraljka Gall-Trošelj, Borka Kušić, Nives Pećina-Šlaus, Krešimir Pavelić and Jasminka Pavelić \\ Division of Molecular Medicine, Laboratory of Molecular Oncology, Ruder Bošković Institute, Zagreb, Croatia
}

(Received March 6/July 11, 1995)

Summary: Testing for the presence of hepatitis $\mathrm{C}$ virus (HCV) in blood derivatives used in clinical medicine is of enormous importance to ensure the production of safe preparations. So far, no system has been developed for the isolation and detection of hepatitis $\mathrm{C}$ virus from blood derivatives. The recently introduced commercial kit for the detection of hepatitis $\mathrm{C}$ virus is designed for the isolation and detection of virus from blood serum.

A reliable and reproducible method for the isolation of hepatitis $C$ virus RNA, subsequent reverse transcription and nested polymerase chain reaction (PCR) from blood derivatives is described. Of 17 batches of factor VIII, $\gamma$-globulin and anti tetanus, cytomegalovirus and Varicella-zoster immunoglobulin concentrates, respectively (14 negative for anti HCV and 3 of unknown anti HCV status) five were found positive in RNA-PCR.

\section{Introduction}

Hepatitis $C$ virus, a positive single stranded RNA virus, is a major cause of non $\mathrm{A}$, non $\mathrm{B}$ hepatitis throughout the world. Until 1990, the serological diagnosis of hepatitis $\mathrm{C}$ virus infection based on detection of antibodies against viral particles was the only method of choice. In 1990 the polymerase chain reaction (PCR), a powerful tool to detect trace amounts of hepatitis $\mathrm{C}$ nucleic acid, was described. Since then, a large number of papers has been published on RNA-PCR based detection, mostly in serum or plasma samples (1-4). However, non $A$, non $B$ hepatitis is also a well-known complication of the treatment of patients suffering from blood disorders. Therefore, evaluation of the safety of blood derivatives that are used for replacement therapy is of utmost importance. The existing, recently developed kit for the isolation and detection of hepatitis $\mathrm{C}$ virus is designed for blood serum testing but not for testing commercial blood derivatives used in therapy.

In this paper we describe a modification of RNA-PCR for detecting hepatitis $C$ virus sequence in experimental samples of coagulation factor VIII, $\gamma$-globulin as well as anti cytomegalovirus, tetanus and Varicella-zoster immunoglobulin derivatives.

\section{Materials and Methods}

\section{Samples}

Seventeen experimental batches of coagulation factor VIII, $\gamma$-globulin and anti cytomegalovirus, tetanus and Varicella-zoster immunoglobulin derivatives of human origin, respectively (prepared from outdated, several years old remainders of 17 experimental series of the products manufactured by the Institute of Immunology, Zagreb, Croatia) were tested. The concentrates were prepared from plasma pools (collected from the local population) (negative for anti hepatitis $\mathrm{C}$ virus and human immunodeficiency virus 1 ). All lyophilized concentrates were stored at $4{ }^{\circ} \mathrm{C}$, while the serum samples (hepatitis $\mathrm{C}$ virus positive patients - positive control; healthy donors - negative control) were aliquoted immediately after collection and stored at $-70^{\circ} \mathrm{C}$.

\section{RNA extraction}

For RNA extraction, $400 \mu$ l of serum, or half the volume of a microcentrifuge tube $(1.5 \mathrm{ml})$ of lyophilized concentrate was mixed with $1 \mathrm{ml}$ of solution containing $4 \mathrm{~mol} / \mathrm{l}$ guanidinium thiocyanate, $25 \mathrm{mmol} / 1$ sodium citrate, $\mathrm{pH} 7.0,5 \mathrm{~g} / \mathrm{l}$ sarkosyl and $0.1 \mathrm{~mol} / \mathrm{l} 2$ mercaptoethanol. The samples were vigorously shaken and the dissolved fraction of lyophilized blood derivatives was split in two tubes. To each tube $12.5 \mu \mathrm{l}$ of $2 \mathrm{~mol} / 1$ sodium acetate $(\mathrm{pH} 4.0)$, $500 \mu \mathrm{l}$ water saturated phenol and $100 \mu \mathrm{l}$ chloroform : isoamyl alcohol $(24+1$, by vol.) were added. The samples were mixed vigorously, incubated for 15 minutes on ice and centrifuged at $15800 \mathrm{~g}$ for 10 minutes at $4^{\circ} \mathrm{C}$. The upper phase was collected and precipitated overnight at $-20^{\circ} \mathrm{C}$ in an equal volume of isopropanol. After centrifugation, $15800 \mathrm{~g}, 20$ minutes, $4^{\circ} \mathrm{C}$, the pellet was extracted again with $150 \mu \mathrm{l}, 4 \mathrm{~mol} / \mathrm{l}$ guanidinium thiocyanate, 
$25 \mathrm{mmol} / \mathrm{l}$ sodium citrate, $\mathrm{pH} 7.0,5 \mathrm{~g} / 1$ sarkosyl and $0.1 \mathrm{~mol} / \mathrm{l} 2-$ mercaptoethanol as well as $150 \mu \mathrm{l}$ chloroform : isoamyl alcohol $(24+1)$ and centrifuged, $15800 \mathrm{~g}, 2$ minutes, $4^{\circ} \mathrm{C}$. The aqueous phase was again extracted with an equal volume of chloroform : isoamyl alcohol and centrifuged as before. RNA was precipitated from the upper phase by adding $1 / 10$ volume of $2 \mathrm{~mol} / \mathrm{l}$ sodium acetate and 2.5 volumes of absolute ice cold ethanol and incubating for 4 hours at $-20^{\circ} \mathrm{C}$. The pellet obtained by centrifugation at $15800 \mathrm{~g}, 20$ minutes, $4^{\circ} \mathrm{C}$ was washed with $70 \%$ ethanol and centrifuged at $15800 \mathrm{~g}$ for 5 minutes at room temperature. The visible RNA pellet was dissolved in $20 \mu \mathrm{l}$ of sterile, deionized water and the concentration was determined spectrophotometrically. Endogenous ribonucleases were inhibited by RNasin. All other precautions to avoid ribonuclease activity recommended throughout the literature (use of gloves, baked glassware, autoclaved plastic ware etc.) were observed.

\section{Polymerase chain reaction}

For reverse transcription $\left(42^{\circ} \mathrm{C}\right.$ for one hour) $5 \mu l$ denatured (7- 10 minutes, $\left.70^{\circ} \mathrm{C}\right) \mathrm{RNA}, 2 \mu \mathrm{l}$ of reaction buffer II $(100 \mathrm{mmol} / \mathrm{l}$ Tris $\mathrm{HCl}, \mathrm{pH} 8.3,500 \mathrm{mmol} / 1 \mathrm{KCl}$, Perkin Elmer), $2 \mu \mathrm{l}$ dNTPs ( $2.5 \mathrm{mmol} / \mathrm{l}$ each), $\mathrm{MgCl}_{2} 4 \mu \mathrm{l}(25 \mathrm{mmol} / \mathrm{l}), 2 \mu \mathrm{l}$ dithiothreitol (100 $\mathrm{mmol} / \mathrm{l}), 200 \mathrm{U}$ of Moloney murine leukaemia virus reverse transcriptase (BRL) and $30 \mathrm{pmol}$ hepatitis $\mathrm{C}$ virus $\mathrm{H} 7$ outer antisense primer were used;in a total volume of $20 \mu$ l. For hepatitis $C$ virus DNA-PCR we used two pairs of primers (outer antisense 5'-GATGCACGGTCTACGAGACCTC-3' and sense 3'-AACTACTGTCTTCACGCAGAA-3'; inner antisense 5'-GCGACCCAACACTACTCGCT-3' and sense 5'-ATGGCGTTAGTATGAGTG-3') based on the highly conserved 5 ' untranslated region, described by Lazizi et al. (3). The predicted product size bordered by outer primers ( $\mathrm{H} 7$ antisense, $\mathrm{H}-8$ sense) was 288 base pairs. The inner primers (H-9 antisense, $\mathrm{H}-10$ sense) flanked a 187 base pairs long region. Before PCR the cDNA was heat denatured $\left(95^{\circ} \mathrm{C}, 5 \mathrm{~min}\right)$. The reaction was performed in a Perkin-Elmer-Cetus Thermal Cycler in triplicate, always including a positive and negative control. The whole reverse transcription product $(20 \mu \mathrm{l})$ was used for the first round of PCR amplification which was carried out in $100 \mu \mathrm{l}$ volume by the addition of the Taq polymerase (1.25 U, Perkin-Elmer Cetus), $\mathrm{MgCl}_{2}$ to a final concentration of $2.5 \mathrm{mmol} / \mathrm{l}, 8 \mu \mathrm{l} \mathrm{PCR}$ reaction buffer II $(100 \mathrm{mmol} / \mathrm{l}$ Tris $\mathrm{HCl}, \mathrm{pH} 8.3,500 \mathrm{mmol} / / \mathrm{KCl}$, Perkin Elmer) and 120 pmol of outer primers. The 40 -fold amplification profiles underwent denaturation at $95^{\circ} \mathrm{C}$ for 65 seconds, annealing at $42^{\circ} \mathrm{C}$ for 2 minutes and extension at $72^{\circ} \mathrm{C}$ for $2 \mathrm{~min}$ utes. The final extension step lasted for 10 minutes. The PCR products were analyzed by agarose gel electrophoresis ( $2 \%$ agarose stained with $0.5 \mathrm{mg} / \mathrm{l}$ ethidium bromide). After the first round of amplification only a smear was visible and, therefore, $3-5 \mu \mathrm{l}$ of the first hepatitis $C$ virus PCR product was submitted to a second PCR amplification with inner primers (120 pmol each) under the previously described conditions. Precautions were employed to prevent false-positive (due to contamination) results and a negative control (RNA omitted from the reaction mixture) was included in all experiments.

\section{Southern blot}

Southern blots were performed to confirm that the first round amplificate contained specific hepatitis $C$ virus cDNA. The nested PCR product (187 base pairs) was partially purified as previously described (5) and then used as a probe. The samples were run on agarose gels and transferred to nylon membranes. The membranes were prehybridized for 4 hours at $42{ }^{\circ} \mathrm{C}$ in a solution containing $0.75 \mathrm{~mol} / \mathrm{l} \mathrm{NaCl}, 75 \mathrm{mmol} / \mathrm{l} \mathrm{Na}$ citrate, Denhardt's solution $(1 \mathrm{~g} / 1$ Ficoll $400,1 \mathrm{~g} /$ polyvinylpyrrolidone, $1 \mathrm{~g} / 1$ bovine serum albumin) $0.5 \mathrm{l} / 1$ formamide, $10 \mathrm{~g} / 1 \mathrm{SDS}, 50 \mathrm{mmol} / 1$ sodium phosphate, $\mathrm{pH}$ $6.8,100 \mathrm{~g} / 1$ dextran sulfate and $100 \mathrm{mg} / \mathrm{l}$ denatured salmon sperm DNA, and then hybridized for 48 hours at $42{ }^{\circ} \mathrm{C}$ with ${ }^{32} \mathrm{P}$ labelled $\left(10^{8}\right.$ counts $\left./ \mathrm{min} \cdot \mu \mathrm{g}\right)$ hepatitis $\mathrm{C}$ virus probe. Finally, the membranes were washed in $30 \mathrm{mmol} / \mathrm{l} \mathrm{NaCl}, 3 \mathrm{mmol} / \mathrm{l} \mathrm{Na}$ citrate,
$1 \mathrm{~mol} / \mathrm{l} \mathrm{SDS}$ at $70^{\circ} \mathrm{C}$ for 15 minutes, and autoradiographed for three days at $-70^{\circ} \mathrm{C}$ using an intensifying screen.

\section{Testing for antibodies to hepatitis $C$ virus}

The presence of anti-hepatitis $C$ virus antibodies was assayed in duplicate in 96 well plates by enzyme immunoassay (UBI HCV EIA, United Biomedical Inc., Organon Teknika) according to the manufacturer's instructions. The presence or absence of antibodies specific for hepatitis $\mathrm{C}$ virus is determined by relating the absorbance (at $492 \mathrm{~nm}$ ) of the specimens to the cut off value $(0.205)$. Specimens with absorbance values greater or equal to the cut off value are defined as positive.

\section{Results}

Of the 17 experimental samples of blood derivatives (14 anti hepatitis $C$ virus negative and 3 of unknown anti hepatitis $C$ virus status) five were positive for hepatitis C virus RNA (tab. 1) when tested on agarose gels after the nested polymerase chain reaction. A band of 187 base pairs was seen in one factor VIII concentrate sample (shown in fig. 1), four $\gamma$-globulin derivatives (not shown) and in one hepatitis $\mathrm{C}$ virus positive serum (fig. 1).

However, when the PCR products of RNA hepatitis C virus positive samples obtained after the first round of amplification with outer pair of primers were tested for the presence of a hepatitis $C$ virus RNA, none of the samples yielded a clearly visible fragment (predicted size 288 base pairs). Instead, amplified DNA appeared as a smear, even in hepatitis $C$ virus positive serum sam-

Tab. 1 Hepatitis C virus status of blood derivatives.

\begin{tabular}{|c|c|c|}
\hline Sample & $\begin{array}{l}\text { hepatitis C } \\
\text { virus, PCR }\end{array}$ & $\begin{array}{l}\text { anti hepatitis C } \\
\text { virus }{ }^{1}\end{array}$ \\
\hline 1. $\gamma$-globulin & - & - \\
\hline 2. $\gamma$-globulin & - & N.D. ${ }^{2}$ \\
\hline 3. $\gamma$-globulin & - & N.D. \\
\hline 4. $\gamma$-globulin & - & - \\
\hline 5. $\gamma$-globulin & - & - \\
\hline 6. $\gamma$-globulin & + & - \\
\hline 7. $\gamma$-globulin & + & - \\
\hline 8. $\gamma$-globulin & + & - \\
\hline 9. $\gamma$-globulin & + & - \\
\hline 10. $\gamma$-globulin & - & - \\
\hline 11. factor VIII & + & N.D. \\
\hline 12. $\operatorname{tg}^{3}$ & - & - \\
\hline 13. tIg & - & - \\
\hline 14. $\mathrm{tIg}$ & - & - \\
\hline 15. $\mathrm{RIg}^{4}$ & - & - \\
\hline 16. $\mathrm{CMVIg}^{5}$ & - & - \\
\hline 17. $\mathrm{VZIg}^{6}$ & - & - \\
\hline
\end{tabular}

1 UBI HCV EIA (United Biomedical Inc., manufactured by Organon Teknika)

2 not done (manufactured before 1990)

3 anti tetanus immunoglobulin

4 anti D Rho immunoglobulin

5 anti cytomegalovirus immunoglobulin

6 anti Varicella-zoster immunoglobulin : 
ples. That the first round amplificates still contained specific hepatitis $\mathrm{C}$ virus cDNA (non visible on agarose gel) was further confirmed by Southern blot analysis. Figure 2 shows positive reactivity of one of these samples - factor VIII concentrate along with hepatitis C virus positive serum.

Beside being useful for testing blood derivatives our system has been found useful for testing blood serum, although it is not as simple to use as a commercial kit. The results obtained by testing the serum of patients with hepatitis C (8 samples, one of which is shown in figs. 1 and 2 ) and the serum of healthy donors (12 samples, one of which is shown in fig. 1)

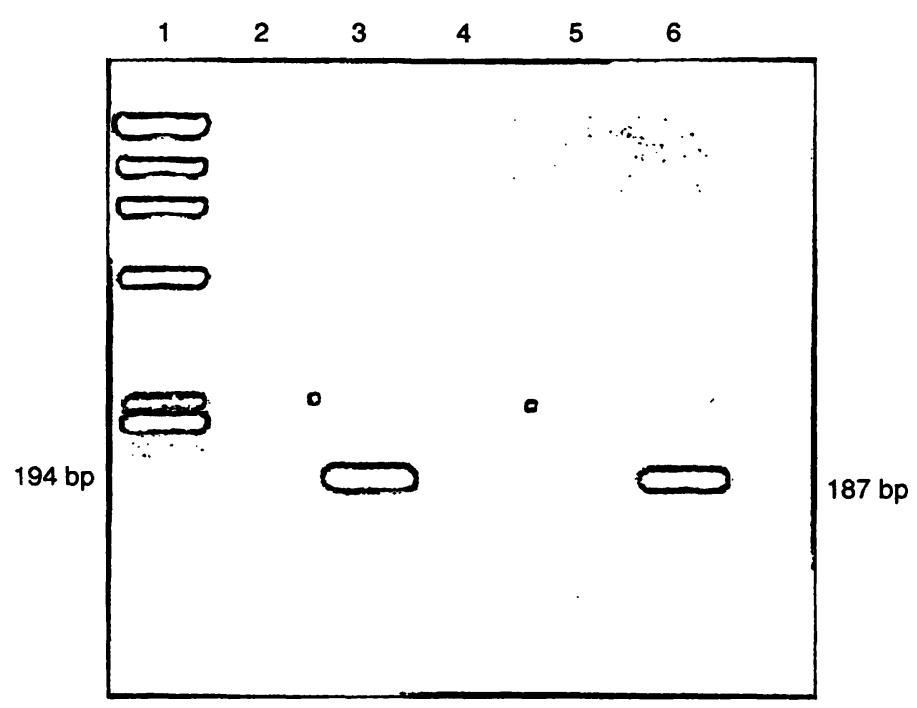

Fig. 1 Detection of hepatitis $C$ virus cDNA by nested PCR. Lane 1: molecular mass marker, $\varphi \times 174 /$ HaellI digest.

Lanes 2 and 3: hepatitis $C$ virus positive serum $(15 \mu l)$ after the first (lane 2) and second (lane 3) PCR reaction;

Lane 4: hepatitis $C$ virus negative serum after the second PCR reaction:

Lanes 5 and 6: factor VIII concentrate $(15 \mu l)$ (sample \# 11) after the first (lane 5) and second (lane 6) PCR reaction.

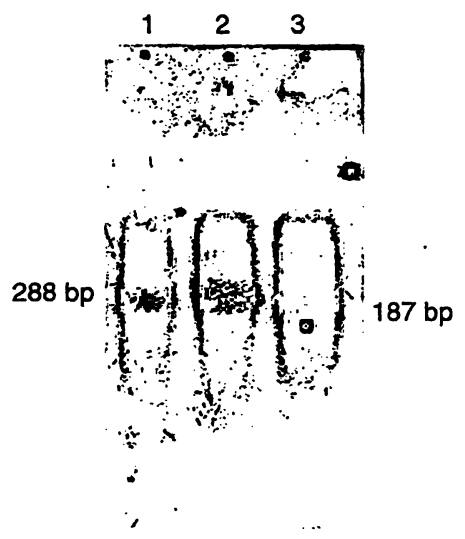

Fig. 2 Southern blot of hepatitis $C$ virus $\mathrm{CDNA}$ obtained after the first round of PCR.

Lane 1: $20 \mu \mathrm{l}$ factor VIII concentrate;

Lane 2: $20 \mu$ l hepatitis $C$ virus positive serum;

Lane 3: hepatitis $C$ virus probe (187 base apairs; $1 \mathrm{ng}$ ). constitute evidence that this method was also reliable in these cases.

\section{Discussion}

Transmission of hepatitis $\mathrm{C}$ virus by commercial blood derivatives has become a major problem among recipients of blood derivatives. Attempts by manufacturers to prevent hepatitis $\mathrm{C}$ virus, based mostly on sterilization, seems not to be sufficient. Prospective studies in the USA and Western Europe have shown that about $80 \%$ of patients transfused with blood products developed anti hepatitis $\mathrm{C}$ virus antibodies and to a lesser degree become hepatitis $\mathrm{C}$ virus carriers. The proportion of infected individuals that will develop liver cirrhosis or hepatocellular carcinoma is still not known. A serological screening for anti hepatitis $\mathrm{C}$ virus in blood derivatives reduces the risk of infection spread but is unlikely to detect all infectious material. The presence of hepatitis $\mathrm{C}$ viral sequences detected by PCR is a better predictor of viral contamination than serological testing. Although PCR is the most sensitive method for hepatitis $\mathrm{C}$ virus detection, it is important to realize the risk of false negative results, possibly due to failure of RNA extraction, reverse transcription or PCR reaction, especially when using commercial blood derivatives where the viral genome is present in a low copy number. PCRdetection of hepatitis $\mathrm{C}$ virus in factor VIII concentrates and commercial immunoglobulins has been described recently $(6,7)$. However, the results relating to hepatitis $C$ virus RNA detection show discrepancies among different laboratories. Total RNA isolation, the crucial step in hepatitis $\mathrm{C}$ virus RNA detection, described in our paper is different from that used initially by Garson et al. (6). We isolated RNA by guanidinium thiocyanate. This is an excellent method for isolation of minute amounts of very unstable mRNA (such as wild type p53 mRNA). Garson et al. used a polyethylene glycol based isolation method. In a paper of Castillo and co-workers (8), three different hepatitis $C$ virus $\mathrm{RNA}$ isolation procedures from serum samples (proteinase digestion, polyethylene glycol precipitation, guanidinium thiocyanate) were compared. The authors found guanidinium thiocyanate to be the most suitable for hepatitis C virus RNA isolation (8). Although time consuming, trace amounts of RNA could be precipitated overnight at $-20^{\circ} \mathrm{C}$. In our previous experiments precipitation at $-70^{\circ} \mathrm{C}$ for either one hour or overnight significantly reduced the amount of total RNA. Precipitation time and temperature may be critical for hepatitis $\mathrm{C}$ virus RNA isolation. We found the best RNA yield after overnight precipitation at $-20^{\circ} \mathrm{C}$. Garson precipitated RNA at $-70^{\circ} \mathrm{C}$.

Before PCR we always included a RNA denaturation step which seems to be crucial for adequate priming in 
reverse transcription. Castillo et äl. (8) reported total absence of a PCR band if the RNA denaturation step was omitted. There is no reference regarding a denaturation step in Garson's paper.

The method for RNA extraction we described is reliable and reproducible, and special attention should be given to the following: only the guanidinium thiocyanate RNA extraction procedure works well for blood derivatives in our hands; during RNA extraction the chemicals should be kept at $4{ }^{\circ} \mathrm{C}$ to obtain visible precipitates; the precipitation should be done at $-20^{\circ} \mathrm{C}$, overnight (not at $-70^{\circ} \mathrm{C}$ ); diethyl pyrocarbonate should be omitted from the RNA extraction procedure because it can modify RNA molecules and enzyme activity. The tubes with the sample should be vigorously shaken after the addition of each substance. The reaction should be done at least

\section{References}

1. Bartolomé J, Castillo I, Quiroga JA, Navas S, Carreño V. Detection of hepatitis C virus RNA in serum and peripheral blood mononuclear cells. J Hepatol 1993; 17 (3 Suppl):90S-3S.

2. Garson JA, Tedder RS, Briggs M, Tuke P, Glazenbrook J, Trude $A$, et al. Detection of hepatitis $C$ virus sequences in blood donations by "nested" polymerase chain reaction and prediction of infectivity. Lancet 1990; 335:1419-22.

3. Lazizi Y, Elfassi E, Pillot J. Detection of hepatitis $C$ virus sequences in sera with controversial serology by nested polymerase chain reaction. J Clin Microbiol 1992; 30:941-4.

4. Puoti M, Zonaro A, Ravaggi A, Marin MG, Castelnuovo F, Cariani $E$. Hepatitis $C$ virus $R N A$ and antibody response in the clinical course of acute hepatitis $C$ virus infection. Hepatology 1992; 16:877-81.

5. Brown MAD. Sequencing with Taq polymerase. In: Innis MA, Gelfand DH, Sninsky JJ, White TJ, editors. PCR protocols: a guide to methods and applications. New York: Academic Press, 1989:189-96.

6. Garson JA, Tuke PW, Makris M, Briggs M, Machin SJ, Preston $\mathrm{FE}$, et al. Demonstration of viraemia patterns in haemophiliacs in triplicate to reduce the possibility of false positive results.

From our experience the evaluation of the safety of blood derivatives, based on hepatitis $C$ virus RNA detection, should be a condition for its commercial use.

The information given in this paper is in accordance with current needs and World Health Organization recommendations for the prevention of hepatitis $C$ virus infection by blood derivatives. We hope they will help researchers in devising more precise and simpler methods for viral RNA detection.

\section{Acknowledgements}

We thank Drs. B. Benko and $A$. Vince for providing experimental batches of the blood derivatives and patient sera for this study.

treated with hepatitis-C-virus contamined factor VIII concentrates. Lancet 1990; 336:1022-5.

7. Lefrère JJ, Mariotti M, Trepo C, Li JS, Lunel F, Frangeul L, et al. Testing for HCV-RNA in commercial intravenous immunoglobulins. Lancet 1993; 341:834-5.

8. Castillo I, Bartolomé J, Quiroga JA, Carreño V. Comparison of several PCR procedures for detection of serum HCV-RNA using different regions of the HCV genome. J Virol Meth 1992; 38:71-9.

Dr. Jasminka Pavelić

Division of Molecular Medicine

Laboratory of Molecular Oncology

Ruđer Bošković Institute

Bijenička 54

P.O.B. 1016

HR-10001 Zagreb

Croatia 